INOBIS: Jurnal Inovasi Bisnis dan Manajemen Indonesia

Volume 04, Nomor 02, Maret 2021

Fathul Bachri, Nihayatu Aslamatis Solekah

\title{
Organizational Commitment as Mediating Variable of Employee Job Satisfaction Toward Turnover Intentions
}

\author{
Fathul Bachri \\ UIN Maulana Malik Ibrahim Malang, Indonesia \\ Nihayatu Aslamatis Solekah \\ UIN Maulana Malik Ibrahim Malang, Indonesia \\ *aslamatiss_1@pbs.uin-malang.ac.id
}

\begin{abstract}
The high employees turnover at PT. BRI Syariah shows low job satisfaction and organizational commitment and high desire to change jobs. The purpose of this study was to determine the effect of job satisfaction and organizational commitment on turnover intentions directly or indirectly. Quantitative methods are used in this study. The population is employees at PT. BRI Syariah of Malang Branch with 50 people. The sampling technique used was census sampling with sample size of 50 people. Data collection techniques using questionnaires and path analysis. The results of the study indicated that there is negative and significant effect of job satisfaction on turnover intentions, positive and significant effect of job satisfaction on organizational commitment, negative and significant effect of organizational commitment on turnover intentions, and negative and significant effect of job satisfaction on turnover intentions indirectly through organizational commitment.
\end{abstract}

Key Words: Job Satisfaction, Organizational Commitment, Turnover Intentions

\section{Introduction}

One of the hot issues being discussed is the turnover issue. Recent trends in employee turnover have increased equally across the globe. The impact of turnover which becomes the main loss of organization is the time and new costs for employee recruitment. This makes many companies experience frustration because qualified employees obtained from recruitment prefer to work in other company organizations. One of the companies facing the employee turnover problem is PT. BRI Syariah. In 2017, the company experienced high employee turnover. Based on BRI Syariah Sustainability report data, (2017) that the level of turnover experienced by PT. BRI Syariah is dominated by resignation from employees. The number of employees who resign becomes disadvantage for each company because it certainly will greatly hamper organizational performance. The existence of negative effect between turnover on organizational performance, high turnover rates have impact on the decline in organizational performance. Employee turnover certainly cannot be separated from turnover intention. Robbins and Judge (2011) argue that turnover intentions is the most dominating factor that is positive for turnover. This means that when the employee's intention to move is higher, the employee turnover will be greater. Turnover intention can be seen as the subjective probability of individuals who will change or change jobs within certain period. One factor that is considered as turnover intention antecedent is job satisfaction.

Job satisfaction can be seen as employees' perceptions of how well their work gives them what is considered important (Luthans, 2006). Some studies that examine the relationship 
between the effect of job satisfaction on turnover intention include research (Putri and Prasetio, 2017) which indicates strong relationship between job satisfaction and turnover intention, then Luz and Oliveira's (2016) research revealed that job satisfaction can predict turnover intention. Several studies have been conducted to explore these factors affect employee turnover intentions (Djebarni and Kamel, 2011; Ertosun and Erdil, 2012; Walker and Campbell, 2013; Ibrahim and Perez, 2014)

The high level of turnover from employees can also be seen as result of the low level of organizational commitment, it can be interpreted as situation where employees take sides and feel part of the members so there is desire to remain in the company. High employee turnover is the result of low employee desire to remain in the organization. Robbins and Judge (2007) define organizational commitment as condition where a member sits with the organization and its goals and desires to maintain its membership in the organization. The relationship between organizational commitment and job satisfaction is supported by Kell \& Motowidlo (2012) which states that job satisfaction and organizational commitment are attitudes that determine certain behaviors.

In addition to the relationship between job satisfaction variables and organizational commitment to turnover intention, previous research also shows that job satisfaction is precursor of the variable organizational commitment. Hidayat (2018) conducted study on organizational commitment at PT Toyamilindo employees, the result was positive and significant effect of job satisfaction on organizational commitment. In addition, Ismail \& Razak (2016) said that when employees feel satisfied in their work extrinsically or intrinsically from their work conditions can provide greater organizational commitment.

Interestingly, the factor that most causes the turnover of BRI Syariah banks is due to resignation, this is interesting point for the authors to conduct this research at BRI Syariah banks, even supported by the statement of Marthis and Jackson (2001), people who satisfied with his work will be more committed to the organization and someone who is dissatisfied with his work or who is less committed to the organization will look withdrawn from the organization. These statements raise the question, whether the turnover rate shown by BRI Syariah employees is also directly affected by organizational commitment or indirectly through job satisfaction. So this study aims to examine the direct effect of job satisfaction on Turnover Intention and organizational commitment of BRI Syariah of Malang Branch employees. To test the direct effect of Organizational Commitment on Turnover Intention of BRI Syariah of Malang Branch employees. To test the indirect effect of Job Satisfaction on Turnover Intention through Organizational Commitment from BRI Syariah of Malang Branch employees

\section{Literature Review and Hypothesis}

\section{Organizational Commitment}

According to Ketchan and Strawser (2001) Organizational Commitment is concept that seeks the nature of love that is formed by individuals towards their work. Robbins and Judge (2011) define Organizational Commitment as an employee's condition in favor to particular company and its goals, and intends to maintain its membership in the company. In other words, organizational commitment is related to the high desire of employees to share and sacrifice for the company.

Organizational commitment according to Luthans (2006) as organizational commitment attitude often defined as aspects that mark the high commitment of a person to the organization, namely:(1) A strong desire to remain as member of the organization (2) Willingness to mobilize all its capabilities for the success of the organization, and (3) Acceptance of organizational values and goals 
An organizational commitment shows person's power in identifying his involvement as organizational part. Organizational commitment is built on the basis of workers' trust in organizational values, the willingness of workers to help realize organizational goals and loyalty to remain become member of the organization. Therefore organizational commitment will create feeling of belonging to workers towards the organization.

Allen and Meyer (1997) state that there are three degrees of organizational commitment: Affective Commitment is commitment that occurs when employees want to be part of company because of emotional bond. In other words, strong affective commitment will identify employee by being actively involved and enjoying his membership in the company. Employees recognize the similarities between themselves and the company, thus showing concern and consequently forming impressive commitments. In addition, the employee is willing to give up his personal values and adjust to the company. Affective Commitment is part of Organizational Commitment that refers to the emotional side inherent in an employee related to his involvement in an organization. There is tendency that employees who have strong Affective Commitment will always be loyal to the organization where they work. There are several divisions of Affective Commitments that have been identified including personal characteristics, structural characteristics, characteristics related to work, and work experience, where work experience has the strongest and most consistent relationship. Employees who have worked long enough in an organization that is always consistent in the expectations expected and the satisfaction of basic needs will tend to form stronger affective ties to the organization than employees who have less experience or less satisfied needs (Allen and Meyer, 1997)

The second is the sustainability commitment. This commitment is based on the employee's perception of the loss he would have if he did not continue his work in the company. In other words, the employee stays with a company because he needs salary and other benefits or because he has not found another job (need). This commitment arises when individuals realize that the accumulation of their investment will be lost if they leave the organization (side batch) or individuals realize the limited alternatives that are comparable to their organizations at this time so that individuals need the organization (need to).

The third is Normative Commitment. This commitment arises from the self-values of employees who remain members of the company because there is an awareness that commitment to the company is a must or obligation (Allen and Meyer, 1997). These employees only stay in the company because they feel it is right to do so. Normative commitment is the employee's feelings about the obligations that must be given to the organization. The normative component develops as a result of the socialization experience, depending on the extent of the employee's sense of obligation. Commitment that occurs when employees continue to work for the organization caused by pressure from other parties to continue working in the organization. This commitment refers to a reflection of the feeling of its obligation to become an employee of the company. Employees with high normative commitment feel that these employees should continue to work in the organization where they work now. In other words, the commitment that exists in the employee is caused by the employee's work obligations to the organization

\section{Job satisfaction}

Robbins and Judge (2011) view Job Satisfaction as positive feeling to a job, which is the impact/ results of evaluations from various sides of the job. Meanwhile, according to Mangkunegara (2009) Job Satisfaction is the extent to which employee feels positive or negative about work, which is a psychological response to one's duties as well as physical and social conditions in the work environment. In short Job Satisfaction can be summed up as 
something that makes people want and like their work because they feel happy in doing their work.

According to Robbins and Judge (2007) individuals who do not achieve job satisfaction will never achieve psychological maturity and can become frustrated. Factors that affect employee job satisfaction include: Individual factors (gender, age, personal attitude towards work), Factors of relations between employees (relations between superiors and employees, social relations between fellow employees, suggestions from coworkers), Physical factors and workplace conditions, emotions and work situations) external factors (family circumstances, recreation, education).

\section{Turnover Intentions}

According to Allen and Meyer (1997) turnover intentions awareness to have the desire to find alternative work in other organizations. Which means, Turnover Intentions are the thoughts of employees about leaving the organization voluntarily. Employee turnover leads to the final reality faced by the company (lost a number of employees) in certain period, while Turnover Intentions itself refers to the results of individual evaluations regarding the continuation of its relationship with company that has not been manifested in concrete actions leaving the company. Therefore, efforts to control and reduce employee turnover can be started by eliminating employee turnover intentions (Pareke, F. J. 2007; Wijayanti, F. C., 2005).

Staff turnover can reduce organizational performance and require expensive replacement costs for replacement costs. Retention of these workers is a concern and priority for Human Resource professionals (Mathieu et al., 2016). Intention is desire that arises in an individual to do something. While turnover is the movement of an employee from his place of work voluntarily. It can be defined that turnover intentions are the inclination or intention of employees to voluntarily leave their jobs according to their own choice.

Turnover intentions is picture of thoughts about going out to look for work elsewhere, and the desire to leave the organization (Sumarto, 2009). Therefore, the behavior that appears from a person when turnover intention arises in him is looking for better vacancies elsewhere. Turnover intentions are under individual control, so they can provide research results that are faster and relatively predictable compared to their turnover behavior. Turnover intention in this study is seen from indicators according to Michaels and Spector (1982): Thinking of quitting, Intention to search for alternatives, Intention to quit

\section{Effect of Job Satisfaction on Turnover Intentions}

The conceptual framework of the effect of job satisfaction on turnover intention is based on previous research by Mathieau et., al (2016) showed that job satisfaction has effect on employee turnover. Putri and Prasetio (2017) said job satisfaction has negative effect on turnover intentions. The study states that to maintain and improve employee satisfaction is done by taking into account the needs of employees and facilities so that it can make employees feel at home working in the company to reduce the level of turnover intentions. From the previous research, the hypothesis raised in analyzing the effect of job satisfaction on turnover intentions is

\section{H1: It is hypothesized that there is direct effect of Job Satisfaction on Turnover Intentions}

\section{Effect of Job Satisfaction on Organizational Commitment}

Marthis and Jackson (2001) stated that people who are relatively satisfied with their work will be more committed to the organization and someone who is dissatisfied with their work or who is less committed to the organization will appear to withdraw from the organization. The conceptual framework of the effect of job satisfaction on organizational 
commitment is based on previous research by Hidayat (2018) stated that job satisfaction has positive effect on organizational commitment, job satisfaction is antecedent from organizational commitment. Ismail and Razak (2016) got the results that individual job satisfaction has positive effect on organizational commitment. Furthermore, this study divides job satisfaction into intrinsic and extrinsic satisfaction, both of which have significant role in organizational commitment. From the previous research, the hypothesis raised in analyzing the effect of job satisfaction on organizational commitment is.

$\mathrm{H} 2$ : It is hypothesized that there is effect of Job Satisfaction on Organizational Commitment

\section{Effect of Organizational Commitment on Turnover Intentions}

Robbins and Judge (2011) define Organizational Commitment as an employee's condition in favor of a particular company and its goals, and intends to maintain its membership in the company. In other words, organizational commitment is related to the desire of employees to remain members of the organization. Thus, if the organizational commitment of employees is high, the lower level of desire of employees to leave the company organization. The conceptual framework of the effect of organizational commitment on turnover intention is based on previous research by Wateknya (2016) which stated that there is negative and significant effect between organizational commitment to turnover intention. Luz and Oliveira (2016) stated that commitment consisting of affective and normative commitment has negative and significant effect on the desire for turnover. From the previous research, the hypothesis raised in analyzing the effect of organizational commitment on turnover intention is H3: It is hypothesized that there is direct effect of Organizational Commitment on Turnover Intention

\section{Effect of Job Satisfaction on Turnover Intention through Organizational Commitment}

Kell \& Motowidlo (2012) which stated that job satisfaction and organizational commitment are attitudes that determine certain behaviors. In other words, job satisfaction and organizational commitment together have effect on turnover intention. The conceptual framework of the job satisfaction effect on turnover intention through organizational commitment is based on prior research by Putra and Wibawa (2015) in his study entitled The Effect of Job Satisfaction on Turnover Intention with Organizational Commitment as an Intervening Variable in PT. Autobagus Rent Car Bali states that job satisfaction has a significant direct effect on turnover intention and there is an indirect effect between job satisfaction on turnover intention that is mediated through organizational commitment. From the previous research, the hypothesis raised in analyzing the effect of job satisfaction on turnover intention through organizational commitment is

H4: It is hypothesized that there is direct effect of job satisfaction on turnover intention through organizational commitment

These hypothesized are highlighted in Figure 1. 


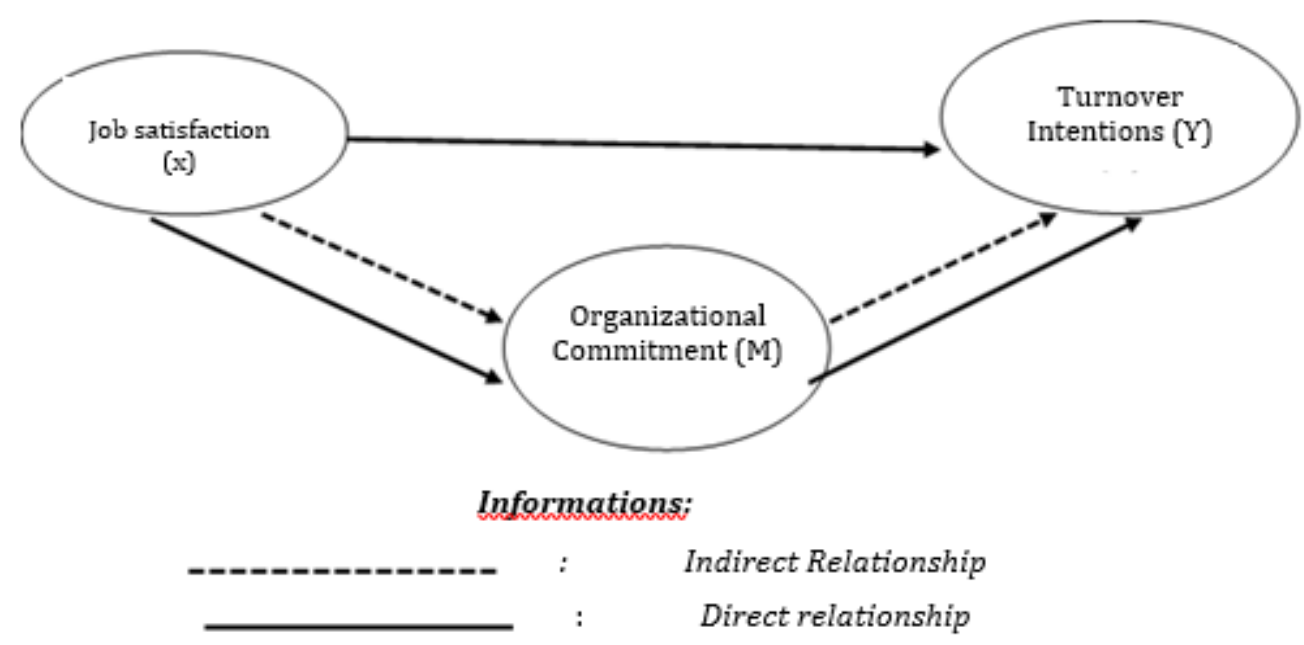

Figure 1. Research Hypothesis Framework

(Source: Processed by Author 2020)

\section{Method}

The research used technique of sampling the census, so that all of the population can be sampled. Sample of 50 employees. The data collection method is carried out by distributing questionnaires to all employees at Bank BRI Syariah of Malang Branch. The measurement scale used in this study is Likert scale, with 5 level assessment interval for each respondent's answer. All data was tested with Path Analysis (Path Analysis) and test Sobel (Sobel test) by using Micorsoft Excel 2016 and SPSS for Windows version 21.0.

\section{Result and Discussion}

From the test results of the job satisfaction effect on the desire to change job, the effect of job satisfaction test on organizational commitment, and the effect of organizational commitment test to turnover intentions can be seen in table 1 .

The results show that job satisfaction negatively effects turnover intention with coefficient of -0.594 with significance of $0.000<0.05$. This means that the higher the job satisfaction of employees, the lower the desire of employees to change jobs. Likewise job satisfaction variable has positive effect on organizational commitment with coefficient of 0.567 with significance of $0.000>0.05$. This means that the higher employee job satisfaction the higher the organizational commitment of the employee. For the test results of effect of organizational commitment to the desire to change job has negative effect with coefficient of 0.558 and significance of $0.000<0.05$. This shows that the higher the organizational commitment of employees the lower the desire of employees to change jobs. And all the hypothesis tests have proven to be accepted.

The test results of job satisfaction with the turnover intentions with path analysis shows that job satisfaction (salary, work itself, supervision, promotion opportunities, colleague relations) directly affects the desire of employees to change jobs, and the effect exerted is negative and significant. The results support previous research conducted by Putri and Prasetio (2017), variable job satisfaction has a negative and significant effect on turnover intention or the desire to change jobs. 
INOBIS: Jurnal Inovasi Bisnis dan Manajemen Indonesia

Volume 04, Nomor 02, Maret 2021

Fathul Bachri, Nihayatu Aslamatis Solekah

Table 1. Job Satisfaction Test Results Towards turnover intentions and Organizational Commitment through turnover intentions

\begin{tabular}{|c|c|c|c|c|c|}
\hline Model & B & Std error & $\begin{array}{c}\text { Standarized } \\
\text { Coefficients }\end{array}$ & T & Sig \\
\hline Job satisfaction (X1) & $-0,473$ & 0,092 & $-0,594$ & $-5,122$ & 0,000 \\
\hline \multicolumn{7}{|c|}{ Dependent Variable: turnover intentions } \\
\hline Job satisfaction (X2) & 0,938 & 0,197 & 0,567 & 4,768 & 0,000 \\
\hline \multicolumn{7}{|c|}{ Dependent Variable: Organizational commitment } \\
\hline $\begin{array}{l}\text { Organizational } \\
\text { Commitment (M) }\end{array}$ & $-0,268$ & 0,058 & $-0,558$ & $-4,656$ & 0,000 \\
\hline \multicolumn{7}{|l|}{ Dependent Variable: turnover intentions } \\
\hline
\end{tabular}

(Source: Data Processed 2020)

The test results of job satisfaction effect on organizational commitment with path analysis get the results that job satisfaction (X) directly effect the organizational commitment (M) positively and significantly. This means that the employees satisfaction regarding salary, their work, supervision, promotion, and their colleagues has effect on the organizational commitment of employees. So it can be concluded that job satisfaction is antecedent of organizational commitment. These results support the support of Hidayat (2018), Ismail and Razak (2016) which states that job satisfaction is antecedent of organizational commitment, although Ismail and Razak (2016) divides job satisfaction into intrinsic and extrinsic satisfaction.

The test results of organizational commitment on turnover intention show that organizational commitment (affective, normative, sustainable) directly affects the desire of employees to change jobs negatively and significantly. Proven high commitment of affective, normative and continuing employees have effect in reducing the desire to move the work of the employees that, seen from the respondents to statement of turnover intention that the majority provide answers tend toward disagree and strongly disagree. These results support Wateknya (2016), which stated that there is negative and significant effect between organizational commitment and turnover intention

Hypothesis Testing Results of the Job Satisfaction effect on the Desire to Change job through Organizational Commitment which is tested by the sobel test shows that Organizational Commitment mediates the Job Satisfaction variable on the Desire to Change job negatively. This shows that high organizational commitment by employees due to high employee job satisfaction will reduce the desire of employees to change jobs. For a summary of the path analysis model can be seen in Figure 2, while summary of direct and indirect effects can be seen in Table 2 


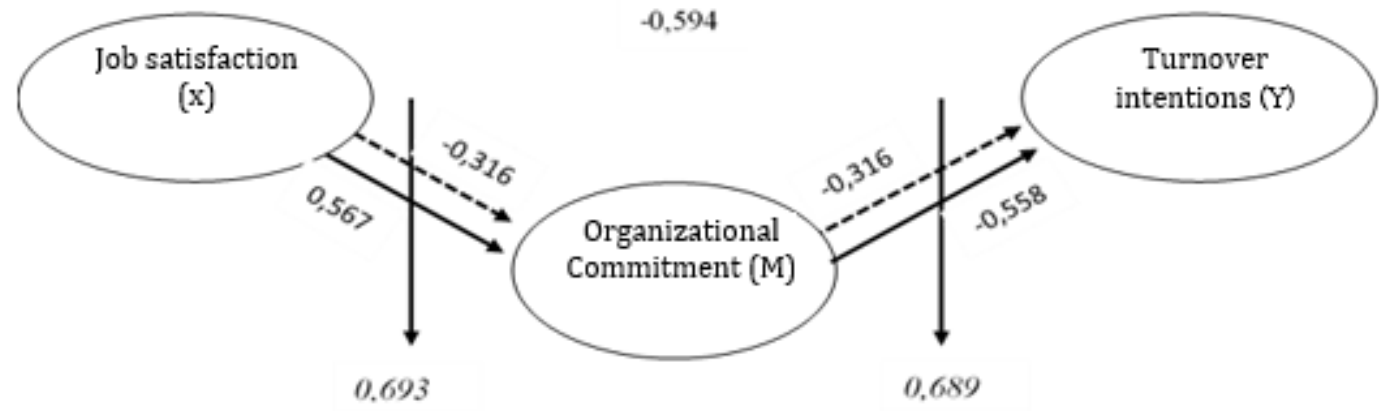

Figure 2 Path Analysis Model

(Source: Data Processed in 2020)

Table 2 Direct and Indirect Effects

\begin{tabular}{|c|c|c|c|c|c|}
\hline \multirow{2}{*}{ Variable } & \multirow{2}{*}{$\begin{array}{c}\text { Path } \\
\text { coefficient }\end{array}$} & \multicolumn{3}{|c|}{ Effect } & \multirow{2}{*}{ Sig. } \\
\hline & & Direct & Indirect & Total & \\
\hline $\mathrm{X} \rightarrow \mathrm{M}$ & 0,567 & 0,567 & & 0,567 & Significant \\
\hline $\mathrm{X} \rightarrow \mathrm{Y}$ & $-0,594$ & $-0,594$ & & $-0,594$ & Significant \\
\hline $\mathrm{M} \rightarrow \mathrm{Y}$ & $-0,558$ & $-0,558$ & & $-0,558$ & Significant \\
\hline $\mathrm{X} \rightarrow \mathrm{M} \rightarrow \mathrm{Y}$ & & & $\begin{array}{c}0,567 \times 0,558 \\
=-0,316\end{array}$ & $-0,316$ & Significant \\
\hline$e 1$ & $\begin{array}{l}\sqrt{1-0,307} \\
=0,693\end{array}$ & 0,693 & & 0,693 & \\
\hline$e 2$ & $\begin{array}{c}\sqrt{ } 1-0,311 \\
=0,689\end{array}$ & 0,689 & & 0,689 & \\
\hline
\end{tabular}

(Source: Data Processed in 2020)

\section{Conclusion}

Job satisfaction directly effect turnover intention negatively and significantly. This shows that the higher the level of employee satisfaction the lower level of turnover intention. In this study it can be concluded that BRI Syariah of Malang Branch employees feel satisfaction at work so the desire to change jobs from BRI Syariah of Malang Branch employees is very low.

Job satisfaction directly affects the organizational commitment positively and significantly. This shows that the higher level of employee satisfaction will affect the high level of commitment owned by employees. In this study it can be concluded that the BRI Syariah of Malang Branch employees feel satisfaction at work that affects the commitment level of BRI Syariah of Malang Branch employees that also increased.

Organizational commitment directly effect turnover intention negatively and significantly. It was concluded that BRI Syariah of Malang Branch employees had high organizational commitment so that the desire to change jobs from BRI Syariah of Malang Branch employees was very low.

Job satisfaction has indirect effect on the desire to change jobs from BRI Syariah employees through organizational commitment. This means that indirectly if job satisfaction of BRI Syariah employees increases, the desire to change jobs will decrease by increasing organizational commitment caused by job satisfaction of employees

Implication of this research is expected to be a consideration to solve the problem of employee turnover intention. From this study, the company should pay more attention to the 
company's closeness to employees psychologically or emotionally, both by means of activities related to policies and by means of activities outside of work. This aims to improve the emotional relationship between employees and the company so that employees feel that the company is within employees. In addition, the implication of this research result is that there are still many employees who work only as a formality, or it can be said that they don't really love the work they do. So it is hoped that the company will be able to change the view of their employees towards their own work. What companies can do is create a more attractive and less boring work atmosphere.

\section{Daftar Pustaka}

Allen and Meyer. (1997). Commitment In The Workplace (Theory, Research and Application). Sage Publication London.

Djebarni, J.A.R. and Kamel, M. (2011). Determinants of job satisfaction in the UAE', Personnel Review, Vol. 40, No. 1, pp.126-146 [online] http://dx.doi.org/10.1108/00483481111095555

Ertosun, Ö.G. and Erdil, O. (2012). The effects of loneliness on employees' commitment and intention to leave', Procedia - Social and Behavioral Sciences, Vol. 41, pp.469-476 [online] http://dx.doi.org/10.1016/j.sbspro.2012.04.057.

Hidayat., A.,S. (2018). Pengaruh Kepuasan Kerja Terhadap Komitmen Organisasi dan Turnover Intention. Jurnal Manajemen dan Pemasaran Jasa Vol. 11 No. 1, 51-66. Doi:http://dx.doi.org/10.25105/jmpj.v10i1.2516

Ibrahim, M.E. and Perez, A.O. (2014). Effects of organizational justice, employee satisfaction, and gender on employees' commitment: evidence from the UAE', International Journal of Business and Management, Vol. 9, No. 2, pp.45-59 [online] http://www.ccsenet.org/journal/index.php/ijbm/article/view/30434

Ismail. A., \& Razak., M.,R.,A. (2016). Effect of Job Satisfaction on Organizational Commitment. Management\&Marketing, volume XIV, issue 1, 25-40

Kell, H. J., \& Motowidlo, S. J. (2012). Deconstructing Organizational Commitment: Associations Among Its Affective and Cognitive Components, Personality Antecedents, and Behavioral Outcomes. Journal of Applied Social Psychology, 42(1), 213-251. https://doi.org/10.1111/j.1559-1816.2011.00874.x

Ketchand, A.A., \& Strawser, J.R. (2001). Multiple Dimensions of Organizational Commitment: Implications for Future Accounting Research. Behavioral Research In Accounting, Volume 13, 221-251 DOI: 10.2308/bria.2001.13.1.221

Luthans, Fred. (2006). Prilaku Organisasi. Edisi 10. Yogyakarta: ANDI

Luz., Carolina Machado Dias Ramalho, Sílvio Luiz de Paula \& Oliveira.,Lúcia Maria Barbosa de. (2016). Organizational commitment, job satisfaction and their possible influences on intent to turnover, Revista de Gestão, Vol. 25 Issue: 1, pp.84-101, https://doi.org/10.1108/REGE-12-2017-00

Mangkunegara, Anwar Prabu. (2009). Manajemen Sumber Daya Manusia Perusahaan. Bandung: PT. Remaja Posdakarya.

Mathieu, C., Fabi, B., Lacoursiere, R., \& Raymond, L. (2016). The Role of Supervisory Behavior, Job Satisfaction and Organizational Commitment on Employee Turnover. Journal of Management and Organization, 22, 113-129. https://doi.org/10.1017/jmo.2015.25

Marthis, Robert L dan John H. Jackson. (2001). Manajemen Sumber Daya Manusia. Jakarta: Salemba Empat. 
Michaels, C. E., and Spector, P. E. (1982). Causes of employee turnover: A test of the Mobley, Griffeth, Hand, and Meglino model. Journal of applied psychology, 67(1), 53.

Pareke, F. J. (2007). Hubungan Keadilan dan Kepuasan Dengan Keinginan Berpindah: Peran Komitmen Organisasional Sebagai Variabel Pemediasi. Jurnal Ilmu Sosial Dan Politik, 9(2)

Putra., I Gst. Ag. Gd. Emdy Mahardika dan Wibawa., I Made Artha., (2015). Pengaruh Kepuasan Kerja Terhadap Turnover Intention dengan Komitmen Sebagai Variabel Intervening pada PT. Autobagus Rent Car Ball. E-Jurnal Manajemen Unud, Vl.4, No.4, 1100-1118

Putri., S., T. dan Prasetio., A.,P. (2017). Pengaruh Kepuasan Kerja Terhadap Turnover Intention (Studi pada Hotel Delonix Karawang). SMART-Study \& ManagementResearch. Vol XIV, No3-2017

Robbins, S. P., \& Judge, T. A. (2007). Organizational behavior (12th ed.). Upper Saddle River, J: Pearson Prentice Hall

Robbins SP, dan Judge. (2011). Perilaku Organisasi, Salemba Empat, Jakarta

Sumarto. (2009). Meningkatkan Komitmen dan Kepuasan Untuk Menyurutkan Niat Keluar. Jurnal Manajemen dan Kewirausahaan, 11(2).

Sustainability Report BRI Syariah. 2017.

Walker, A. and Campbell, K. (2013). Work readiness of graduate nurses and the impact on job satisfaction, work engagement and intention to remain', Nurse Education Today, Vol. 33, No. 12, pp.1490-1495 http://dx.doi.org/10.1016/j.nedt.2013.05.008

Wateknya, Yoga. (2016). Pengaruh Komitmen Organisasi dan Kepuasan Kerja Terhadap Turnover Intention. Skripsi. Fakultas Ekonomi Universitas Negeri Yogyakarta

Wijayanti, F. C. (2005). Pengaruh Kepuasan Kerjadan Komitmen Organisasional Terhadap Keinginan Untuk Keluar (Intensi Keluar) di RSI Hidayatulla Yogyakarta. Jurnal Aplikasi Manajemen, 1(1) 